\title{
Are adolescents attempting to buy cigarettes on the internet?
}

\author{
Jennifer B Unger, Louise Ann Rohrbach, Kurt M Ribisl
}

\begin{abstract}
Objective- To assess the prevalence of, and demographic and smoking behaviour correlates of, attempting to purchase cigarettes via the internet among adolescent current smokers.

Methods- A representative sample of 17181 10th and 12th grade California students completed a written questionnaire on tobacco related attitudes and behaviour during the 1999-2000 school year. Logistic regression analyses were used to determine the variables associated with attempting to purchase cigarettes on the internet.

Results-Among youth under 18 years of age who were current smokers $(n=1689)$, $2.2 \%(95 \%$ confidence interval $1.5 \%$ to $2.9 \%$ reported attempting to purchase cigarettes on the internet. Attempted internet purchases were more likely among younger respondents, males, frequent smokers, and respondents reporting lower perceived availability of tobacco products from retail and social sources.

Conclusions-Few adolescent smokers in California surveyed during the 1999-2000 school year had attempted to obtain cigarettes from the internet. As internet access increases, future studies should examine whether internet cigarette vendors sell to minors and whether adolescents are purchasing cigarettes on the internet.

(Tobacco Control 2001;10:360-363)
\end{abstract}

Keywords: internet cigarette vendors; adolescent smokers; purchasing

Tobacco products appear to be easily accessible to minors via the internet. Using popular internet search engines in 1998, Malone and colleagues ${ }^{1}$ located 108 web sites selling cigars. Many of these web sites had characteristics that made cigar purchases easy and enjoyable for youth, such as accepting non-credit card payments, not requiring proof of age, selling low priced items, and showing attractive images and humorous, sarcastic health warnings. A similar study of internet cigarette vendors conducted from November 1999 to January 2000 identified 90 web sites located in 23 US states. ${ }^{2}$ The most common age verification method for these sites was self verification, whereby customers "certified" that they were of legal age merely by submitting their order. Only $8 \%$ of the internet cigarette vendors reported that they required photographic age identification at the point of delivery, which is the current standard at retail outlets. More than two thirds of sites allowed purchase with money order or certified check, which can be obtained easily by minors without proof of age.

Although there are no published compliance checks measuring youth access to tobacco from Internet vendors, attorney generals from at least 15 states have conducted internet stings and found that children as young as 9 years of age were easily able to purchase tobacco products. $^{3}$ A sting operation in New York found that 24 of 26 web sites sold to minors working with the New York City Department of Consumer Affairs. ${ }^{4}$

Despite a growing awareness of the availability of tobacco products on the internet, the extent to which youth actually attempt to purchase tobacco on the internet is unknown. This study used data from a large statewide sample of California 10th grade (ages 15-16 years) and 12th grade (ages 17-18 years) students to determine the prevalence of, and demographic and smoking behaviour correlates of, attempting to purchase cigarettes via the internet.

\section{Method}

DATA SOURCE

This study used data from a representative sample of 10th and 12th grade students in California $(\mathrm{n}=17181)$. The data were collected in 86 schools in 18 California counties representative of the California population during the 1999-2000 school year as part of the Independent Evaluation of the California Tobacco Control, Prevention, and Education Program. ${ }^{5}$ Within the 18 counties, a sample of high schools that had enrolments of at least 100 students in grades 10 and 12 was randomly selected from two strata: (1) schools that had received a competitive Tobacco Use Prevention Education grant from the California Department of Education; and (2) all other eligible high schools. Within each school, classrooms of students were randomly selected. The survey used an Institutional Review Board (IRB) approved implied consent procedure. Students were assumed to have parental consent if their parents did not return 
Table 1 Demographic characteristics of analytic sample $(n=1689$ California 10th and 12 th grade smokers). Independent Evaluation of the California Tobacco Control, Education, and Prevention Program

\begin{tabular}{|c|c|c|c|}
\hline \multicolumn{2}{|l|}{ Variable } & $\begin{array}{l}n \\
6\end{array}$ & $\frac{\%}{0.4}$ \\
\hline$\overline{\text { Age }}$ & $\begin{array}{l}14 \\
15 \\
16 \\
17\end{array}$ & $\begin{array}{r}6 \\
448 \\
384 \\
851\end{array}$ & $\begin{array}{r}0.4 \\
26.5 \\
22.7 \\
50.4\end{array}$ \\
\hline Grade & $\begin{array}{l}10 \\
12\end{array}$ & $\begin{array}{l}844 \\
845\end{array}$ & $\begin{array}{l}50.0 \\
50.0\end{array}$ \\
\hline Sex & $\begin{array}{l}\text { Male } \\
\text { Female }\end{array}$ & $\begin{array}{l}851 \\
838\end{array}$ & $\begin{array}{l}50.4 \\
49.6\end{array}$ \\
\hline Ethnicity & $\begin{array}{l}\text { White } \\
\text { Latino } \\
\text { Asian/Pacific Islander } \\
\text { Other (African American, American Indian, } \\
\text { multi-ethnic, "other") }\end{array}$ & $\begin{array}{l}952 \\
257 \\
226\end{array}$ & $\begin{array}{l}56.4 \\
15.2 \\
13.4\end{array}$ \\
\hline Frequent & $\begin{array}{l}\text { oked at least } 20 \text { of the past } 30 \text { days) } \\
\text { Yes } \\
\text { No }\end{array}$ & $\begin{array}{l}777 \\
912\end{array}$ & $\begin{array}{l}46.0 \\
54.0\end{array}$ \\
\hline Ever attem & $\begin{array}{l}\text { rchase cigarettes on the internet } \\
\text { Yes } \\
\text { No }\end{array}$ & $\begin{array}{r}37 \\
1652\end{array}$ & $\begin{array}{r}2.2 \\
97.8\end{array}$ \\
\hline Source of & $\begin{array}{l}\text { cigarette purchase } \\
\text { Liquor store } \\
\text { Gas (petrol) station } \\
\text { Convenience store } \\
\text { Small neighbourhood market } \\
\text { Other } \\
\text { Supermarket } \\
\text { Vending machine } \\
\text { Drug store (pharmacy) } \\
\text { Internet } \\
\text { None/missing }\end{array}$ & $\begin{array}{r}399 \\
387 \\
220 \\
203 \\
101 \\
66 \\
23 \\
14 \\
12 \\
264\end{array}$ & $\begin{array}{r}23.6 \\
22.9 \\
13.0 \\
12.0 \\
6.0 \\
3.9 \\
1.4 \\
0.8 \\
0.7 \\
15.6\end{array}$ \\
\hline Asked for & $\begin{array}{l}\text { month } \\
\text { No } \\
\text { Yes }\end{array}$ & $\begin{array}{r}1272 \\
417\end{array}$ & $\begin{array}{l}75.3 \\
24.7\end{array}$ \\
\hline Refused p & $\begin{array}{l}\text { ast month } \\
\text { No } \\
\text { Yes }\end{array}$ & $\begin{array}{r}1302 \\
387\end{array}$ & $\begin{array}{l}77.1 \\
22.9\end{array}$ \\
\hline Perceived & $\begin{array}{l}\text { garettes } \\
\text { Easy or very easy } \\
\text { Hard or very hard }\end{array}$ & $\begin{array}{r}1584 \\
105\end{array}$ & $\begin{array}{r}93.8 \\
6.2\end{array}$ \\
\hline
\end{tabular}

a signed form declining their children permission to participate. Even if their parents did not decline participation, students were free to decline participation. Only $1 \%$ of parents declined participation, and $99 \%$ of students whose parents provided consent chose to participate. During a single class period (45-50 minutes), students completed a paper-and-pencil questionnaire about their tobacco related attitudes and behaviours.

INCLUSION CRITERIA

The analytic sample $(n=1689)$ consisted of those respondents who were less than 18 years of age and were current smokers (had smoked $\geqslant 100$ cigarettes in lifetime and had smoked in the past 30 days).

\section{MEASURES}

To assess internet cigarette purchase attempts, respondents were asked, "During the last year, have you tried to buy cigarettes on the internet?" Demographic variables included age, sex, and ethnicity (African Americans, American Indians, "Others", and multiethnics represented only $1.9 \%, 3.5 \%, 4.9 \%$, and $4.7 \%$ of this sample of smokers, respectively; therefore, they were combined into an "Other" category). Frequent smoking was defined as having smoked on $\geqslant 20$ of the past 30 days. ${ }^{6}$ Past experiences with cigarette purchasing were assessed with questions about whether the respondent had been asked for proof of age to purchase cigarettes in the past month and/or had tried unsuccessfully to purchase cigarettes in the past month. Perceived availability of tobacco was assessed with a question about how difficult it would be for the respondent to obtain a cigarette if he or she wanted one. These measures are described in detail elsewhere.

DATA ANALYSIS

To make the sample representative of the California youth population, the data were weighted according to state school enrolment data, as documented by the California Department of Education (CDE) enrolment databases. Each student received a school weight, created such that when each student's data were multiplied by the student's weight, the sample size for each grade in each school matched the number of students in that grade in that school in the CDE database. The school weights were aggregated to the CDE enrolment counts to create the final weight. The final weight was then divided by the average weight in the dataset to create the relative weight, so that the sum of the weights equalled the survey sample size.

Frequencies were used to describe the demographic characteristics of the sample. Multiple logistic regression analysis was conducted with attempted internet tobacco purchases as the outcome variable (coded $1=$ yes, $0=$ no) and the variables described above used as predictor variables. County, stratum, and school were included in the model as random effect variables to control for intraclass correlation. Odds ratios and 95\% confidence intervals were computed, adjusted for these random effect covariates.

\section{Results}

Table 1 shows the demographic characteristics of the 1689 students who were less than 18 years of age and were current smokers. The mean (SD) age was 16.2 (0.85) years; the sample was $50 \%$ female and ethnically diverse. Also shown in table 1 is the source of the respondents' most recent cigarette purchase. Although only $2.2 \%$ of the respondents reported that they had ever tried to buy cigarettes on the internet, $32 \%$ of those who had tried $(0.7 \%$ of the full sample) reported the internet as the source of their most recent cigarette purchase. The most popular sources for cigarette purchases included liquor stores, gas station mini-marts, and small markets.

Access to cigarettes appeared relatively easy in this sample; fewer than $25 \%$ of the respondents reported that a merchant had asked them for ID or refused to sell them cigarettes in the past month, and $94 \%$ reported that it would be "easy" or "very easy" for them to obtain a cigarette if they wanted one.

Table 2 shows the results of the multiple logistic regression analysis predicting internet tobacco purchase attempts. The variables 
Table 2 Logistic regression predicting internet cigarette purchase attempts among California 10th and 12th grade smokers $(n=1689)$. Independent Evaluation of the California Tobacco Control, Prevention, and Education Program

\begin{tabular}{|c|c|c|}
\hline Variable & $O R$ & $95 \% C I$ \\
\hline Age (years) & 0.55 & (0.37 to 0.82$)$ \\
\hline \multicolumn{3}{|l|}{ Sex } \\
\hline Male & 1.00 & \\
\hline Female & 0.16 & (0.06 to 0.43$)$ \\
\hline \multicolumn{3}{|l|}{ Ethnicity } \\
\hline White & 1.00 & \\
\hline Latino & 0.87 & (0.28 to 2.67$)$ \\
\hline Asian/Pacific Islander & 1.08 & $(0.41$ to 2.87$)$ \\
\hline Other & 2.10 & (0.90 to 4.90$)$ \\
\hline \multicolumn{3}{|c|}{ Frequent smoker (smoked at least 20 of the past 30 days) } \\
\hline No & 1.00 & \\
\hline Yes & 2.26 & (1.08 to 4.73$)$ \\
\hline \multicolumn{3}{|l|}{ Asked for ID in past month } \\
\hline No & 1.00 & \\
\hline Yes & 2.04 & $(0.91$ to 4.56$)$ \\
\hline \multicolumn{3}{|l|}{ Refused purchase in past month } \\
\hline No & 1.00 & \\
\hline Yes & 0.51 & (0.20 to 1.27$)$ \\
\hline \multicolumn{3}{|l|}{ Perceived access to cigarettes } \\
\hline Very hard or sort of hard & 1.00 & \\
\hline Very easy or sort of easy & 0.22 & $(0.10$ to 0.50$)$ \\
\hline
\end{tabular}

All estimates are controlled for the random effects of stratum, county, and school.

significantly associated with a greater likelihood of attempting to purchase cigarettes on the internet were younger age, male sex, frequent smoking, and low perceived access from other sources. Purchase attempts did not differ significantly by strata, county, school, ethnicity, or previous experiences with cigarette purchasing.

\section{Discussion}

Among the California 10th and 12th grade smokers in this study, only $2.2 \%$ had attempted to purchase cigarettes via the internet. Attempting to purchase cigarettes on the internet was higher among younger respondents, males, frequent smokers, and youth who reported lower availability of tobacco products. Previous studies ${ }^{78}$ have found that older teens, girls, and African Americans are more likely to be successful when they attempt to purchase cigarettes in stores. Presumably demographic characteristics are unrelated to adolescents' ability to purchase cigarettes on the internet, although socioeconomic status may influence their access to computers and the internet at home. Unfortunately, socioeconomic status was not assessed in this survey. Perhaps younger adolescents turn to the internet to buy cigarettes because they can easily conceal the fact that they are underage, given the lax age verification procedures of most online vendors. Respondents were more likely to attempt to purchase tobacco on the internet if they believed that their access to tobacco was low. Adolescents may turn to the internet as an alternative source of cigarettes if they are unsuccessful in obtaining them from friends or retail stores.

Although relatively few adolescents in this 1999-2000 California sample attempted to purchase cigarettes on the internet, the internet may represent a potential source of

\section{What this paper adds}

Numerous internet websites sell tobacco products, and many do not require positive proof of age. Although several studies have shown that tobacco products are available to youth on the internet, the extent to which youth actually attempt to purchase tobacco on the internet is not known. This study assessed California adolescents' self reported attempts to purchase cigarettes on the internet. Among 10 th and 12 th grade youth under 18 years of age who were current smokers, $2.2 \%$ reported attempting to purchase cigarettes on the internet. Attempted internet purchases were more likely among younger respondents, males, frequent smokers, and those who reported lower perceived availability of tobacco products from retail and social sources. In 1999-2000, relatively few California youth reported attempting to purchase cigarettes on the internet. Continued monitoring and regulation is needed to prevent the internet from becoming a source of tobacco among youth.

tobacco for underage adolescents with internet access. Preliminary evidence (M Cody, personal communication, 2001) indicates that 18 year old college students were able to purchase money orders in convenience stores, locate cigarette vendors on the internet, order cigarettes from these vendors, and receive delivery without providing proof of age. It seems reasonable to believe that adolescents several years younger would be capable of doing so, as well, by claiming to be 18 years of age without providing a photo ID. Currently, $42 \%$ of US households have internet access at home. ${ }^{9}$ More adolescent smokers may be tempted to buy online as internet access increases, and when adolescents discover that most online vendors sell cigarettes without age verification and that the prices are considerably lower than at local stores. The internet may become a source of cigarettes for youth as retail access becomes increasingly difficult for youth while internet tobacco sales remain largely unregulated. Congressman Martin Meehan (Democrat, Massachusetts) proposed federal legislation in 1999 to prevent illegal tobacco sales to minors on the internet as part of the "Tobacco Free Internet for Kids Act" (H.R. 2914), but this legislation has stalled in the Commerce Committee and has since expired. ${ }^{10}$

\section{LIMITATIONS}

These data are based on self report, and the study questionnaire asked about purchase attempts, rather than successful purchases. Perhaps some of the youth who reported that they tried to purchase cigarettes on the internet did not actually complete the online order form or receive delivery. Further research is needed to understand what motivates adolescents to attempt to purchase cigarettes on the internet (for example, low prices, easier 
access), whether adolescents are successful when attempting to purchase, and approaches to reducing cigarette sales to minors via the internet.

The survey was a representative sample of students attending public schools in California, who had parental consent and student assent to participate. The results may not generalise to out-of-school youth (for example, institutionalised or runaway youth), private school students, and non-participants.

\section{FURTHER RESEARCH}

Many questions about youth internet tobacco purchases remain to be answered in further research. Further studies could assess the proportion of internet tobacco purchase attempts that are successful, the amount of tobacco typically purchased in each order, the frequency of internet tobacco purchases, the most common methods of payment, the most frequently purchased cigarette brands, and the locations at which youth use computers to purchase cigarettes online. A more complete understanding of internet tobacco purchases by underage youth could be instrumental in enacting policies to prevent youth access to tobacco through this new venue.

Data were collected as part of the Independent Evaluation of the California Tobacco Control, Prevention, and Education Program. Data collection for this project was made possible by funds received from the Tobacco Tax Health Protection Act of 1988-Proposition 99, under Contract Number (97-105546) with the California Department of Health Services, Tobacco
Control Section. Data analysis was supported by the University of California Tobacco-Related Disease Research Program (Grant 7KT-0006). The Independent Evaluation Consortium consists of a team of researchers from the Gallup Organization, the University of Southern California, and Stanford University. The analyses, interpretations, and conclusions reached in this paper are those of the authors, not the California Department of Health Services.

1 Malone RE, Bero LA. Cigars, youth, and the internet link. Am f Public Health 2000;90:790-2.

2 Kim AE, Ribisl KM, Hoffman R. Sales practices of Internet cigarette vendors: Are they adequate to prevent minors from buying cigarettes online? Roundtable presented at the Annual Meeting and Convention of the American Public Health Association, Boston, Massachusetts, NoPublic Health

3 Sherer R. States crack down on Web tobacco sales. The Christian Science Monitor. New York, November 8, 2000.

4 Anon. Getting smokes online: Children buying cigarettes with click of mouse. ABCNEWS.com. Washington DC; March 6, 2001. Available at: http://wysiwyg://56://abcnews. go.com/sectio...orningAmerica/GM010306Internet cigs. ho.ml.

5 Independent Evaluation Consortium. Final report of the independent evaluation of the California Tobacco control, independent evaluation of the California Tobacco control, prevention and education program: wave 1 data, 1996-1997

6 Centers for Disease Control and Prevention. Youth risk behavior surveillance-United States, 1999. MMWR Surveillance Summaries 2000;49(SS05):1-96.

7 Landrine H, Klonoff EA, Campbell R, et al. Sociocultural variables in youth access to tobacco: replication 5 years later. Prev Med 2000;30:433-7.

8 O'Grady B, Asbridge M, Abernathy T. Analysis of factors related to illegal tobacco sales to young people in Ontario. Tobacco Control 1999;8:301-5.

9 United States Department of Commerce and the National Telecommunications and Information Administration. Falling through the net: toward digital inclusion - a report on American's access to technology tools. Washington DC, 2000.

10 Congressman Martin T Meehan. Congressman Meehan unveils legislation to protect children from tobacco sales on the internet. URL: http://www.house.gov/aps/list/press/ ma05_Meehan/pr_990824.tobacco.html; August 24, 1999.

"There was no counting the cigarettes he lit in a day. Most of them he forgot, or broke. They lay like sticks of chalk in his CEO ashtray. His biological patchiness was a given-faulty, darkened heart and lungs. But to prolong life was not one of Ravelstein's aims. Risk, limit, death's blackout were present in every living moment. When he coughed you heard the sump at the bottom of a mine shaft echoing."

From: Saul Bellow. Ravelstein. London: Penguin Books, 2001, p54.

Supplied by Melanie Wakefield 